\title{
ミヤオ族の穿闘式木造民家の架構と仕口 一中国貴州省における少数民族の穿闘式木造民家の構法に関する研究一 \\ THE STRUCTURE AND TIMBER CONNECTION OF CHUANDOU-SYSTEM WOODEN HOUSES OF MIAO NATIONALITY
}

- A study on the construction method of chuandou-system wooden houses of minority nationality in Guizhou Province, China -

\author{
李 雪*, 黒田乃生 ${ }^{* *}$, 藤川昌 樹***, 安藤邦 廣 $* * * *$ \\ Xue LI, Nobu KURODA, Masaki FUJIKAWA \\ and Kunihiro ANDO
}

\begin{abstract}
The Chuandou System (pillars-and-transverse-tie-beams) wooden frame is wildly used in Miao people's houses in Qiandongnan region of Guizhou Province of China. The Chuandou System wooden frame is composed of vertical pillars and horizontal beams called "Fang". In this area, the house building is following a traditional production organization that the local carpenters design the house and process wooden components and the setting-up of the frame that is completed by joint work of villagers. By investigating the construction process of $\mathrm{G}$ house in Gongna Village, Qiandongnan region, this study has clarified that five types of the mortise and tenon joints are used in Chuandou systerm wooden. To provide an effectively setting-up construction, the local carpenters should devise the combination of mortise and tenon joints, and also process the horizontal beams (Fang) by different heights and widths in different positions even in the same beam as the shorter area can ensure the beams insert mortise smoothly. Therefore, relatively complicated process skill as well as a simple setting-up frame is developed in this region.
\end{abstract}

Keywords : Qiandongnan region,Chuandou-SystemWooden Houses, Construction Process, Construction Method, 黔東南地域, 穿闘式木造民家, 建設工程, 構法

\section{1. はじめに}

\section{1 研究背景と目的}

貴州省（図 1 ）は中国南西部に位置し、人口の $37.9 \%$ がミヤオ族、 トン族、水族、チワン族などの少数民族である。このうち、黔東南 地域におけるミャオ族トン族の木造民家は穿闘式注 1) 架構を用いた二 階建ての高床式また一部三階建ての半高床式注2)である。本地域の 木造民家の材料は主にコウヨウザン（広葉杉・学名：cunninghamia lanceolata) 1) で、部材は地元の兼業大工注3) が加工し、架構は住民が 共同作業で組み立てる。中国では新農村建設注4) が進行し建設会社に よる画一的な住宅が急増しており、地域の植物資源を用いて地元の 大工の技術と住民の協力で民家を建てる事例は減少している。

「穿闘式」の「穿」は中国語で「挿寸」を意味し、名前のとおり横 架材を柱に挿す構法が特徵である。本地域の木造民家の架構と仕口 は建設工程と関連があると考えられるが、これまでの研究ではほと んどが間取りや様式に注目するか、または民家の建設工程、儀式、 仕口を概観するのみで詳細な構法を踏まえ建設工程との関係に着目 したものはなかった。

そこで、本研究は地域の大工と住民による建築手法を把握すると ともに、建設工程に適応した穿闘式の架構の特徵を考察する。

\section{2 既往研究と本研究の位置付け}

黔東南地域における穿闘式木造民家を研究対象としたものに、 1990 年代の田中ら $\left(1990^{2)} 、 1993^{3}\right)$ によよる一連調査の研究があ る。これはトン族を中心として集落、民家、生活の現状と特徴を紹 介したものである。トン族、ミャオ族の木造民家はいずれも穿闘式 架構で大きな差がないこと、生活の階層が異なることを明らかにし た。その後、李 (2005) ${ }^{4)}$ は 1990 年代の調査データに基づいてミヤ

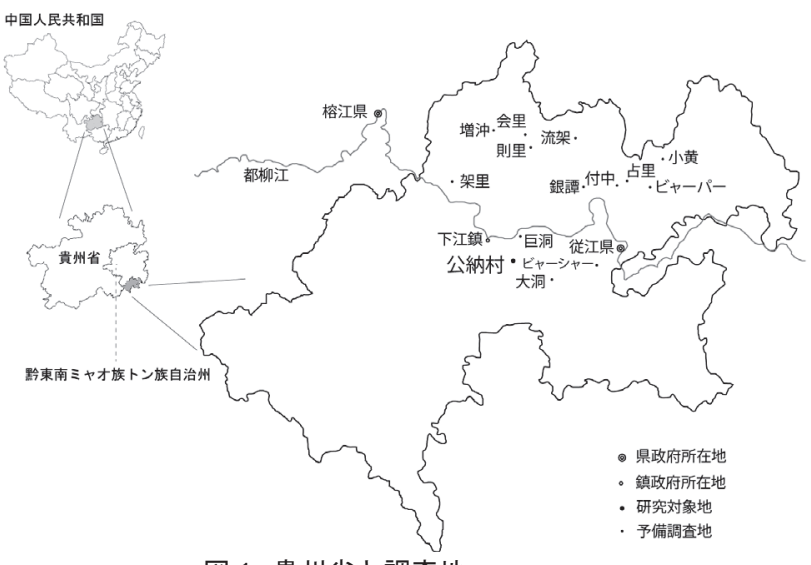

図 1 貴州省と調査地

\footnotetext{
* 筑波大学人間総合科学研究科世界文化遺産学専攻 博士後期課程 ·工修

*** 筑波大学芸術系 教授・博士 (農学)

**** 筑波大学システム情報系 教授・博士 (工学

**** 筑波大学 名誉教授. 工博

Doctal program, World Heritage studies, Graduate School of Comprehensive Human Science, University of Tsukuba, M.Eng.

Prof., Faculty of Art and Design, University of Tsukuba, Ph.D.

Prof., Faculty of Engineering, Information and Systems, University of Tsukuba, Dr.Eng.

Honorary Prof., University of Tsukuba, Dr.Eng.
} 
才族の木造民家の設計手法と構法を明らかにし、田中らの調查に参 加した羅 $(2008)^{5)}$ はトン族の民家の建設工程を紹介したが、いずれ も詳細な組み立ての手順は明らかにしていない。仕口については李 (2005) $^{5)}$ が 4 タイプ注5) (図 2 ) に分類したが、本研究とは異なる結 果を示している。張 (2013) ${ }^{6)}$ はミャオ族の吊脚楼の建設工程、儀式、 伝承を概観したが詳細な建設工程と部材については触れていない。 李ら (2016) ${ }^{7)}$ はミヤ才族の木造民家を対象に建設の生産組織の現状 と村の生活の近代化による生産組織の変化を明らかにしたが構法に ついては述べていない。

民家以外の木造建築を対象としたものとして、片岡ら（2007 注6)、 $\left.2011^{8)}\right)$ はトン族の鼓楼、風雨橋を対象にし、貫構造による構築シ ステムと木割り、仕口の構法と竹尺注7) の記号情報を明らかにした。

本研究はこれらの既往研究を踏まえ、穿闘式木造民家の部材の加 工と架構の組み立ての手順に着目し、仕口構法と部材寸法の特徵を 明らかにしたうえで、構法と建設工程との関係を考察する。

\section{2. 研究方法と研究対象の概要}

\section{1 研究方法}

本研究は現地での観察調查、実測調查、聞き取り調查による。 2013 年 6 月から 11 月にかけて貴州省黔東南におけるミャ才族・ 卜 ン族の 14 箇所注8) の予備調查を行ったところ、田中ら注9) が指摘し たように、トン族ミャオ族の木造民家はいずれも穿闘式架構だった。 集落の大工への聞き取りによると、ミャオ族の集落でトン族の大工 に依頼することや、その逆もあることがわかった。つまり、対象地 域においてトン族とミャオ族の民族による大工技術の差異はないと 考えられる。このため本研究では、建設工程の詳細な調査が可能な ミャオ族の集落の公納村 G 家 (写真 1) を対象とした。2013 年 11 月 5 日から 12 月 20 日まで公納村に滞在し、G 家の新築民家の建設工 程の記録、組み立て前の部材の寸法の実測、および大工への聞き取 りを行った。

\section{2 研究対象の概要}

$G$ 家は主人 (調查当時 39 歳)、父、妻、長男、次男の 5 人家族で 公納村注 10) の一般的な家族構成であり、新築民家の規模、構造、間 取りは村における一般的な住宅であると考えられる注11)。約 30 年前 に建設した旧家屋が老朽化しため、2013 年 11 月 6 日から 12 月 5 日
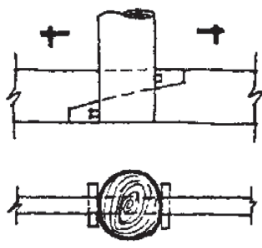

双悄

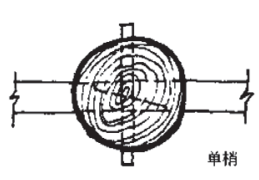

陗法

出典：李先逵，干闌式苗居建築， 中国建築工業出版社, p 76, 2005

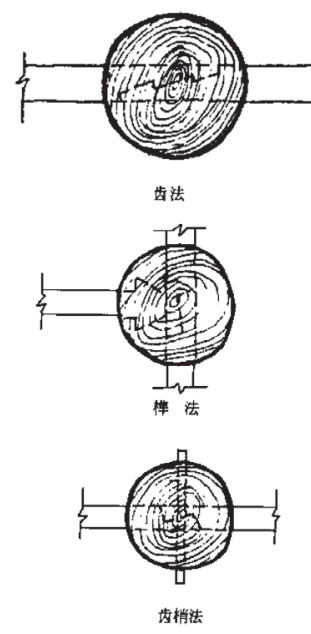

図 2 既往研究での仕口構法
にかけて旧家屋があった敷地に間口 4 間の一部三階建ての入母屋造 りの穿闘式木造民家を新築した。

本地域の木造民家は単位に丈、尺、寸を使い、1 1 丈 $=10$ 尺 $=100$ 寸 であり、1 寸は約 $33 \mathrm{~mm}$ である。G 家の新築民家は桁行が 3.6 丈（約 $11,880 \mathrm{~mm}) 、$ 梁行が 2.8 丈 $(9,240 \mathrm{~mm})$ だった（図 3 )。階高は床下 ( 地盤階）が 7 尺（約 2,310mm）、1階が 8 尺（約 $2,640 \mathrm{~mm}$ ) で、2 階 は 7 尺（約 $2,310 \mathrm{~mm}$ ） だった（図 4 ）。架構の立面図注 ${ }^{12)}$ (図 4 ）が示 すように、黔東南における木造民家の両端の柱間を「厦（シャ）」、厦」 以外の柱間を「間」と呼ぶ。一般に両端の「厦」は同じ寸法、「間」 は均等で、厦」は「間」より狭い。G 家の新築民家は二間二厦であり、 公納村にはほかに一間二厦および三間二厦がある。

公納村の半高床式木造民家は、床下は生産空間で、農作業や家畜 の飼育、車庫として使用され、一階は土間と板床の主要な生活層で ある。G家の一階は中央の「間」は居間として使われ、両脇の「厦」 に階段室、寝室、水回り、火炉が配置された（図 3 )。

\section{3． 穿闘式木造民家の架構と組み立ての手順 \\ 3. 1 穿闘式架構の部材}

黔東南地域の穿闘式木造民家は縦軸の部材の「柱」と柱を貫通す る横架材の「枋」注13) で構成される。

柱は軸組にある基礎から桁まで伸びる「柱」、両側の持ち出しを構 成する「吊柱」と小屋組の「瓜柱」に分かれる。G家新築民家の「柱」 は平均直径約 8.2 寸 $(271 \mathrm{~mm})$ の丸太が使われた。「吊柱」の平均直径 は約 6.1 寸 $(231 \mathrm{~mm})$ であり、「瓜柱」の平均直径は約 4.2 寸 $(140 \mathrm{~mm})$ であった。「柱」と「吊柱」は棟木や母屋桁に達するため、厳密には 軸組と小屋組には分類できないが、本研究では後述する組み立ての 手順を根拠に、いずれも軸組として捉え、「瓜柱」のみを小屋組とする。 枋は梁行の柱を貫通する部材を総称して「排扇枋」注 ${ }^{14)}$ 、梁行の架 構を繋ぐ桁行の「過干枋」注 15$)$ 、小屋組の「瓜枋」に分類できる(図 5 )。 本研究では柱と同様の理由で、「排扇枋」と「過干枋」は軸組とし、「瓜 枋」を小屋組とする。

軸組と小屋組で構成される梁行の架構（図 5 ）は「扇」注 16 ) と呼ば れ、間取りの「間」を構成する。公納村では、軸組の柱は入り口の 反対側から順に 1 柱、 2 柱、中柱（ 3 柱） 注17)、 4 柱、 5 柱注 18)、吊 柱は「 1 柱吊柱」、「 5 柱吊柱」と呼ぶ。「排扇枋」は、下から「千金 下枋」、「千金枋（上、下）」、「出水枋（上、下）」、「水枋（上、下）」、 「三柱枋」と称する。図 5 で示すように、中柱の左側（ 4 柱、 5 柱側

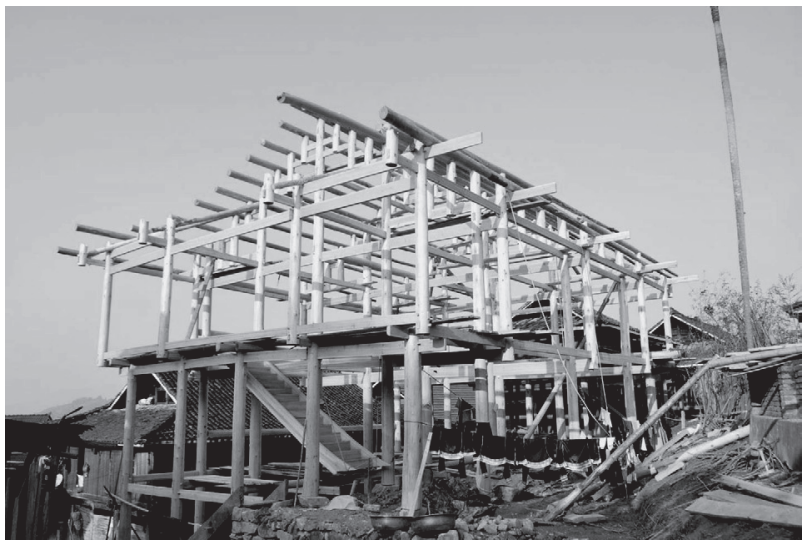

写真 1 G 家の軸組 
）は「上」、右側（ 2 柱、1 柱）は「下」とされる。G 家の新築民家 に用いられた千金下枋は 1 本で長さ 1.63 尺 $(5,384 \mathrm{~mm})$ 、高さ約 5.5 寸 $(182 \mathrm{~mm})$ 、千金枋は上下それぞれ長さ 8 尺 $(2,640 \mathrm{~mm})$ 、高さ約 8 寸 $(264 \mathrm{~mm})$ 、出水枋は上下それぞれ長さ 8 尺 $(2,640 \mathrm{~mm})$ 、高さ約 6.5 寸 $(215 \mathrm{~mm})$ である。水枋は上下ともに長さ 1.15 尺 $(3,784 \mathrm{~mm})$ 、高さ約 6 寸 $(198 \mathrm{~mm})$ だった。「排扇枋」の中でも「千金枋」は上層の荷重が かかる重要な部材であるため注 19)、名称には「貴重」を意味する「千 金」注20)が用いられたと考えられる。「水枋」は小屋組と軒の出を支え、 壁を雨から守る役割がある。また、「千金枋」、「出水枋」の上と下は それぞれ中柱で接合している。

小屋組は「瓜柱」と「瓜枋」で構成される。「瓜柱」は両側から中 央に向かって「瓜柱 1 (上下) 」、「瓜柱 2 (上下) 」、「瓜柱 3 (上下 )」、「瓜柱 4 (上下) 」、「瓜柱 5 ( 上下)」、「瓜柱 6 (上下)」とされる。

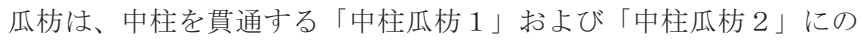
み名前があり、その他は瓜柱と接合する柄に「瓜柱」の名前を表示 し「瓜枋」を区別する。

梁行の架構を繫ぐ横架材の「過干枋」は、下から「過干枋 $1 」$ 、過 干枋 2 」、「過干枋 3 」、「過干枋 4 」、「過干枋 5 」とされる。出水枋、 千金枋、千金下枋に「楼楞 (ねた)」を乗せ、その上に板を張り床 とする。梁行の架構の位置は「排」で表す。G 家は 2 間 2 厦で、正

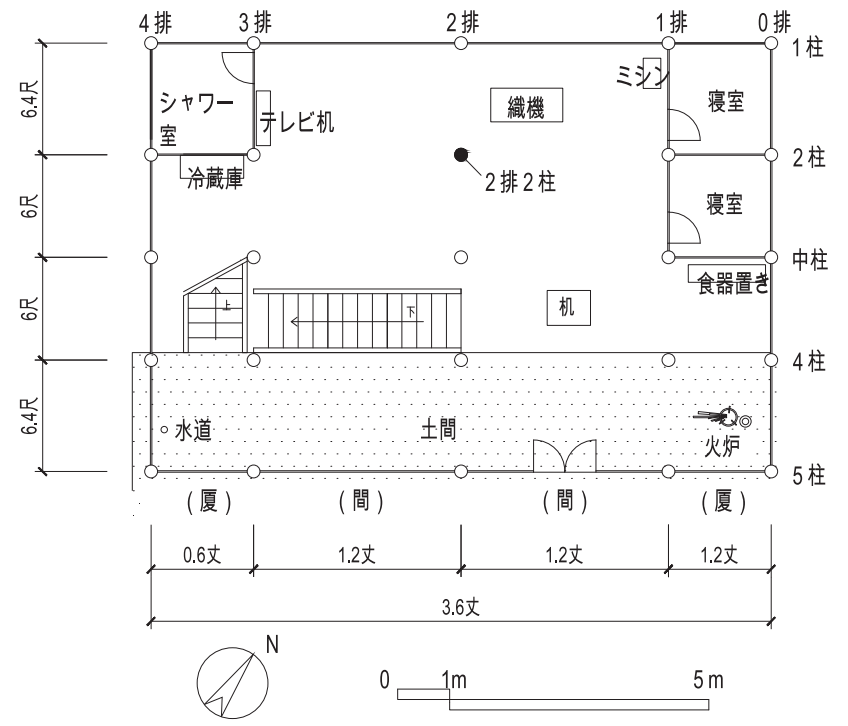

図3 G 家の 1 階平面図

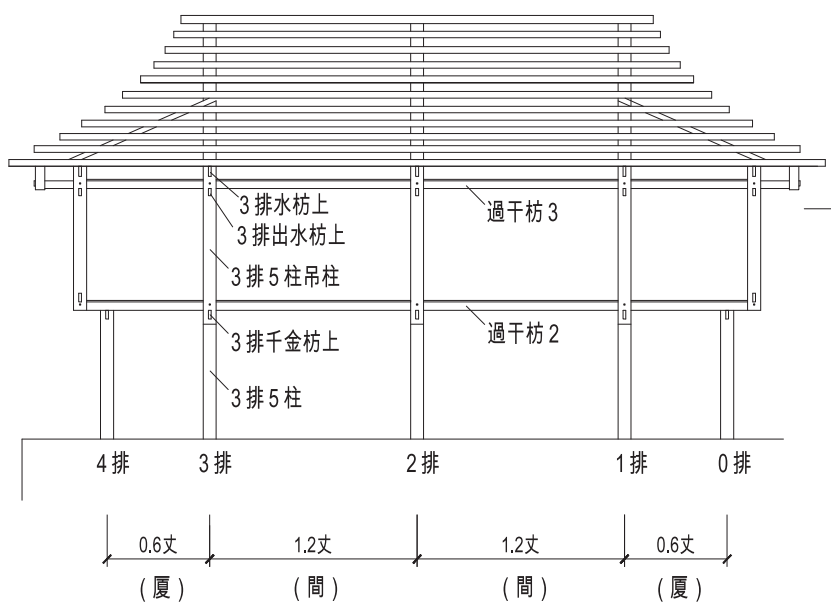

図 4 G 家の架構の立面図
面の右から「0排」、「1排」「 2 排」「 3 排」、「4排」となる（図 3 ）。 柱は「 2 排 2 柱」のように示し、各部材はたとえば「 3 排 5 柱吊柱（図 4)」のように「排」と「柱」または「部材」を組み合わせて示す。

羅 $(2008)$ 注 21) は、トン族の大工は 26 個の「魯班字」と呼ばれる 記号で部材の名前を表示し、そのうちよく使うのは前、後、左、右、上、 下、中、尺、土、掛、梁、方、柱の 13 個と指摘したが、公納村では「上」、 「下」、「方」注22)、「柱」のみであり、かわりに数字を多用している。 「千金枋」や「水枋」のように名称が部材の役割を示すこともあるが、 その他は部材の属性に数字を加えて名称と寸る。例外として「三柱枋」 のみは名称に漢字を用いる。建設工程には複数の大工と村民が参加 するため、部材には簡潔な名称が必要である。「瓜枋」に個々の部材 の名称がなく位置だけを表すように、誰にでも分かりやすい名称に 変化したと考えられる。

\section{2 架構の組み立ての手順}

李ら（2016）注23）によると黔東南地域の木造民家の建設は伐採、 丸太の切断、運搬、製材、部材の加工、整地、「排扇」、上棟、各部 工事により完成する。 $\mathrm{G}$ 家は 2013 年 6 月の伐採から同年 12 月の上 棟まで、作業日数が 36 日、延べ人工が 300 人だった。そのうち、大 工による部材の加工は 12 日、延べ人士は 80 人だった。「排扇（パイ シャン)」は小屋組付の梁行の架構を組み立てる工程で、「上棟」の 前日に村民の共同作業で行われる。G 家は 2 間 2 厦で「扇」は 3 枚 あり、1 日ですべての「排扇」は終了した注24)。「排扇」は 1 日で 20 人工、「上棟」は 1 日で 50 人工、 2 日間で延べ 70 人が参加した注 25$) 。$

「排扇」はまず、敷地に足場を組む ( 写真 2 )。次に、図 6 に示寸 ように、足場に 4 柱、中柱、2 柱を建て架け（図 6-1)、出水枋の上 下、千金枋の上下を、左右から 4 柱と 2 柱を貫通させて中柱で接合し、 千金下枋は右から 2 柱、中柱に差し込む（図 6-2)。5 柱、5 柱吊柱、

1 柱、1 柱吊柱を動かし、それぞれ各排扇枋と接合させる。さらに、

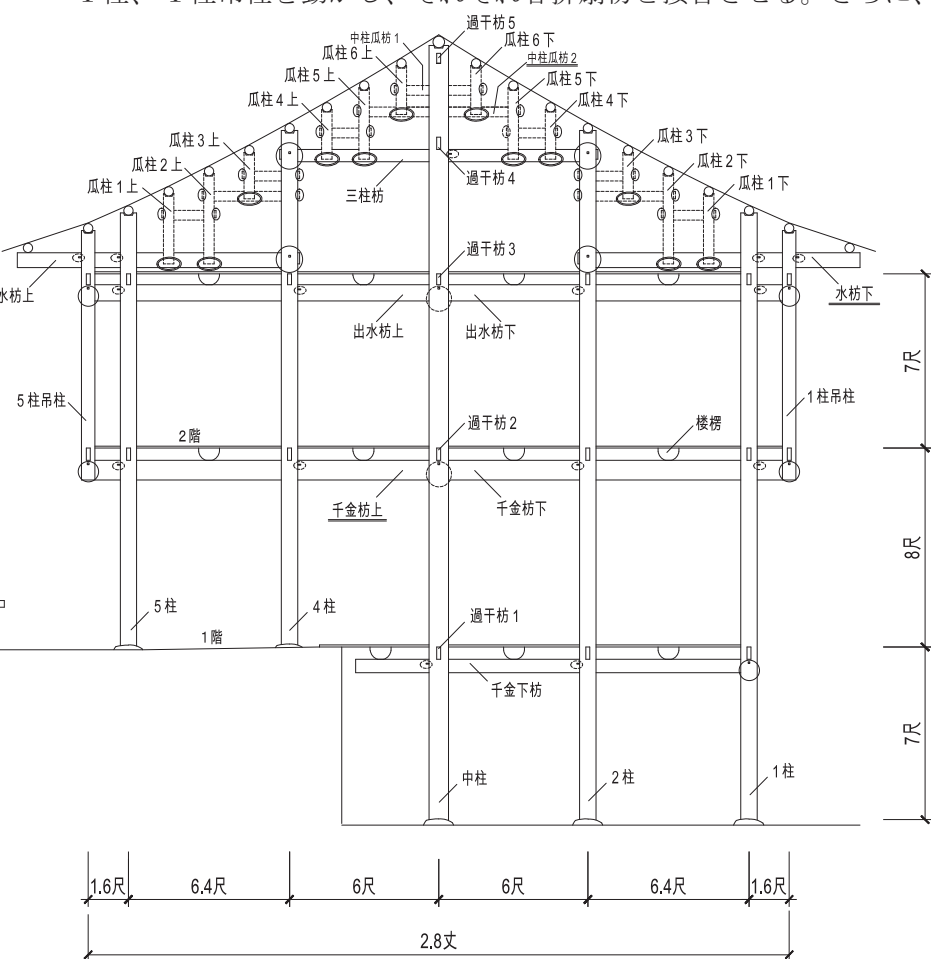

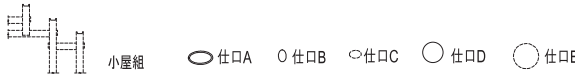

図 5 G 家の架構と部材の名称 
水枋の上下、三柱枋を柱と接合させ軸組が完成する（図 6-3)。最 後に、小屋組の瓜枋と瓜柱を軸組に乗せる (図 6-4)。「排扇」の際、 村民は両側から同時に排扇枋を差し込み、柱で隙間なく接合寸るま で大きな木桘で吒く。強く吒くほど架構が強固になる。

「上棟」は大工の指示に従い 1 日で行う。 1 排、2 排の「扇」を移 動し過干枋でつなぎ、 3 排の「扇」を動かし 2 排の「扇」と過干枋 で繋ぐ。さらに0排と 5 排の軸組を両端に取り付け、最後に階段と 桁を設置し完成させた。

出水枋、千金枋注26) の上下 2 本を左右から柱を貫通して中柱で接 合する構法は、複数の部材を個々に柱に接合する構法に比心゙、効率 的な加工と組み立てが可能である。一方、枋を 1 本の長い材にすると、 木材の運搬や加工・組み立てが困難になる。このため、 2 本の枋を 柱の両側から差し込み中央の柱に接合寸る手法は合理的であると考 えられる。

\section{4. 穿闘式木造民家の仕口構法}

\section{1 仕口構法}

小屋組は仕口 A と仕口 B の 2 種類（表 1)、軸組は仕口 C、仕口 D、 仕口 $\mathrm{E} の 3$ 種類（表 2 ）が見られた。仕口 A と B は、小屋組の瓜柱 と瓜枋を連接する（表 1 ）。A は瓜柱の底部に柄穴を開け、枋材に上 から架ける。柄穴の幅は 1.6 寸 $(53 \mathrm{~mm})$ 、高さは枋材の $3 / 4$ だった。 B は瓜枋の両端にある柄を瓜柱の柄穴に差し込む。 A と B を用いて、 三柱枋、出水枋から軸組へと小屋組の荷重を分散する効果があると 考えられる。

軸組の仕口 C は枋材の両端以外の部分と柱との接続に用いる。柱 を貫通寸る枋材に栓（図７）を打ち込み、枋が柱から抜ける動きを

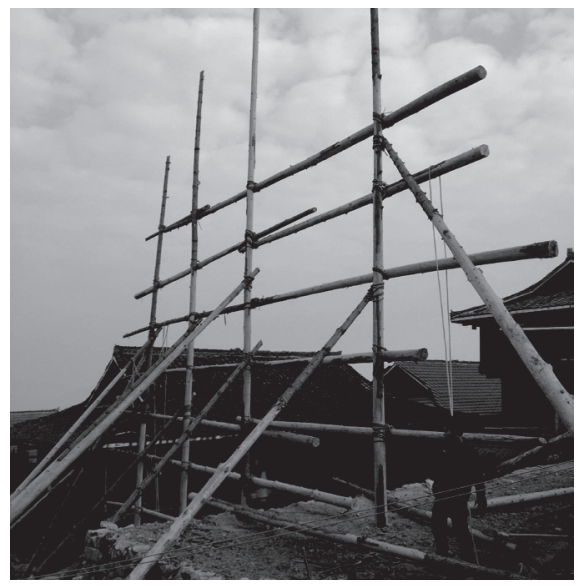

写真 2 敷地と足場

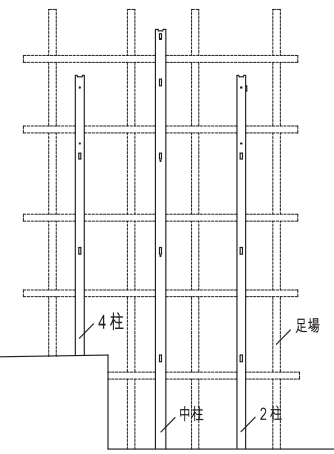

図 6-1 ステップ1

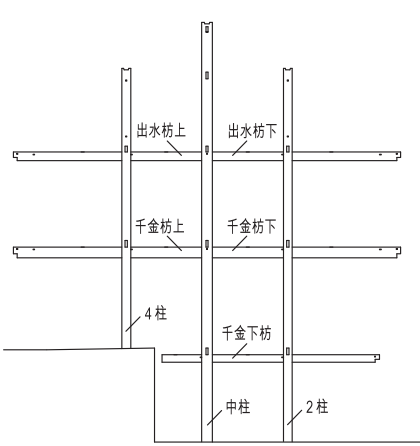

図6-2 ステップ2 (足場略)

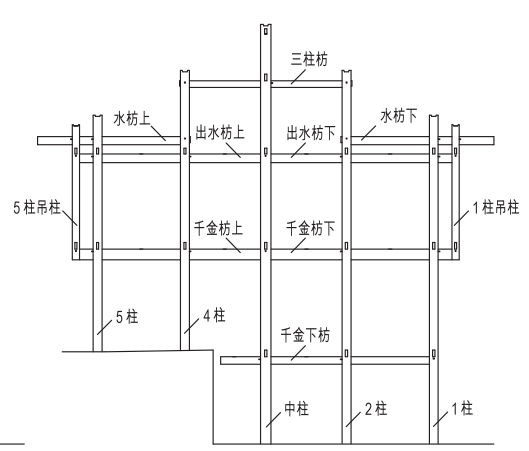

図6-3 ステップ3（足場略） 図 $6 G$ 家の架構の組み立て手順
止める通し一方差し注27) である。三柱枋と中柱、水枋と 1 柱、 5 柱、 吊柱、出水枋および千金枋と 1 柱、 2 柱、 4 柱、 5 柱、千金下枋と 2 柱、中柱の接合に用いられた（図 5 )。

仕口 D と E は込栓を用いる。仕口 D は枋材の端部にある柿を柱の 柄穴に差し込み、込栓（図 8 ）で枋材と柱の水平の動きを止め、柱 と枋の上下も固定する。D は通し一方差しで、三柱枋と 2 柱、 4 柱、 水枋と 2 柱、 4 柱、出水枋、千金枋と吊柱、千金下枋と 1 柱の接合 に用いられた。

仕口 E は公納村では「中穿」と呼ばれ、出水枋の上下、千金枋の 上下を中柱で接合する二方差し注28) である。梁行の架構を繋ぐ過干 枋の接合にも $\mathrm{E}$ を用いる。両側から差し込んだ枋材を柱に接合する、 最も複雑かつ重要な構法と考えられる。仕口の凸部の横断面は基部 1 寸 $(33 \mathrm{~mm})$ 先端 0.6 寸 $(20 \mathrm{~mm})$ の台形で、高さは 4 寸 $(132 \mathrm{~mm})$ で、 長さは柄穴の長さと等しい。下の凹部は上部より 4 寸 $(132 \mathrm{~mm})$ 短く、 長さは穴の端から柱の中心線までと等しい。柄穴で合うように、二 つの柄は対称になっている。図 9 で示すように、柄は幅と長さの接 合で、より安定した構造になると考えられる注29)。

李ら (2016) 注 30) によると木材の伐採から加工までの乾燥期間は最 長 3 个月である。このため、軸組の組み立て完了後も木材は乾燥を 続け、仕口が縮小し変形が生じる場合がある。仕口 E でみられた込 栓による柱と枋の左右および上下の固定は、施工の効率は上がるが 枋の乾燥に伴う縮小によって隙間が生じる可能性がある。公納村で 2014 年に実施した木造民家の悉皆調查では、仕口 $\mathrm{E}$ と異なる接合が 見られた (写真 3 )。柄は柄穴より長く柱の両側に沿って柄に栓を打 ち柱の動きを止め、柄の下に楔 2 本を使って枋の緩みを抑えるもの で、日本の楔と類似している。聞き取りによると、2000 年以降、公 納村に電気が開通し電動工具が使われるようになったため、柱に穴 を開けることが容易になり、仕口 E が主な接合構法になったという。 現代社会にあわせより効率的な構法に変化したが、構造的には課題 があると考えられる。

\section{2 「短竹尺」に用いる仕口 E の加工手法}

黔東南地域の木造民家は、木材を丸太のまま柱に使う。このため、 上から下にかけて太くなったり、曲がったりしており、断面は正円 でない。寸法の基準とする中心線は必ず中央にあると限らず、加工 される柄穴の原寸は木の形にあわせるため設計の寸法と異なる。こ のため、仕口を柄穴に隙間なく接合するためには、それぞれの柄穴 の実寸を計る必要がある。そこで、枋材を挿す方向、柄穴の名前、 穴の寸法などの情報が記載されている長さ約 $40 \mathrm{~cm}$ 、幅約 $1.7 \mathrm{~cm}$ の「短 
表 1 小屋組の仕口構法
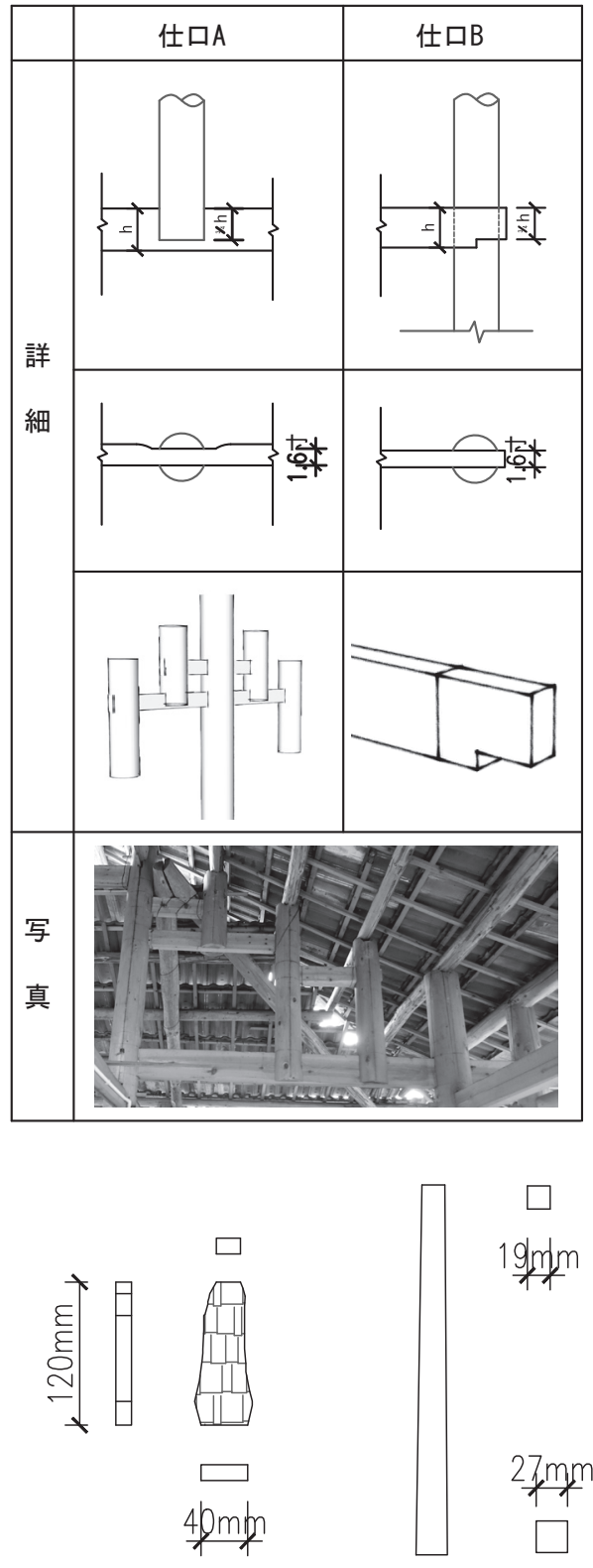

図 7 栓

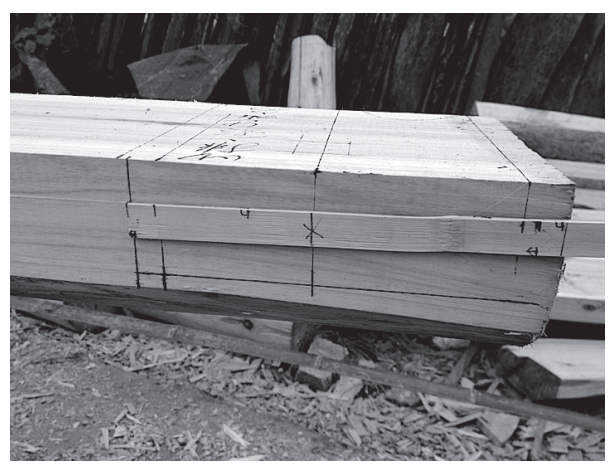

写真 4 短竹尺と墨付けられた仕口
表 2 軸組の仕口構法
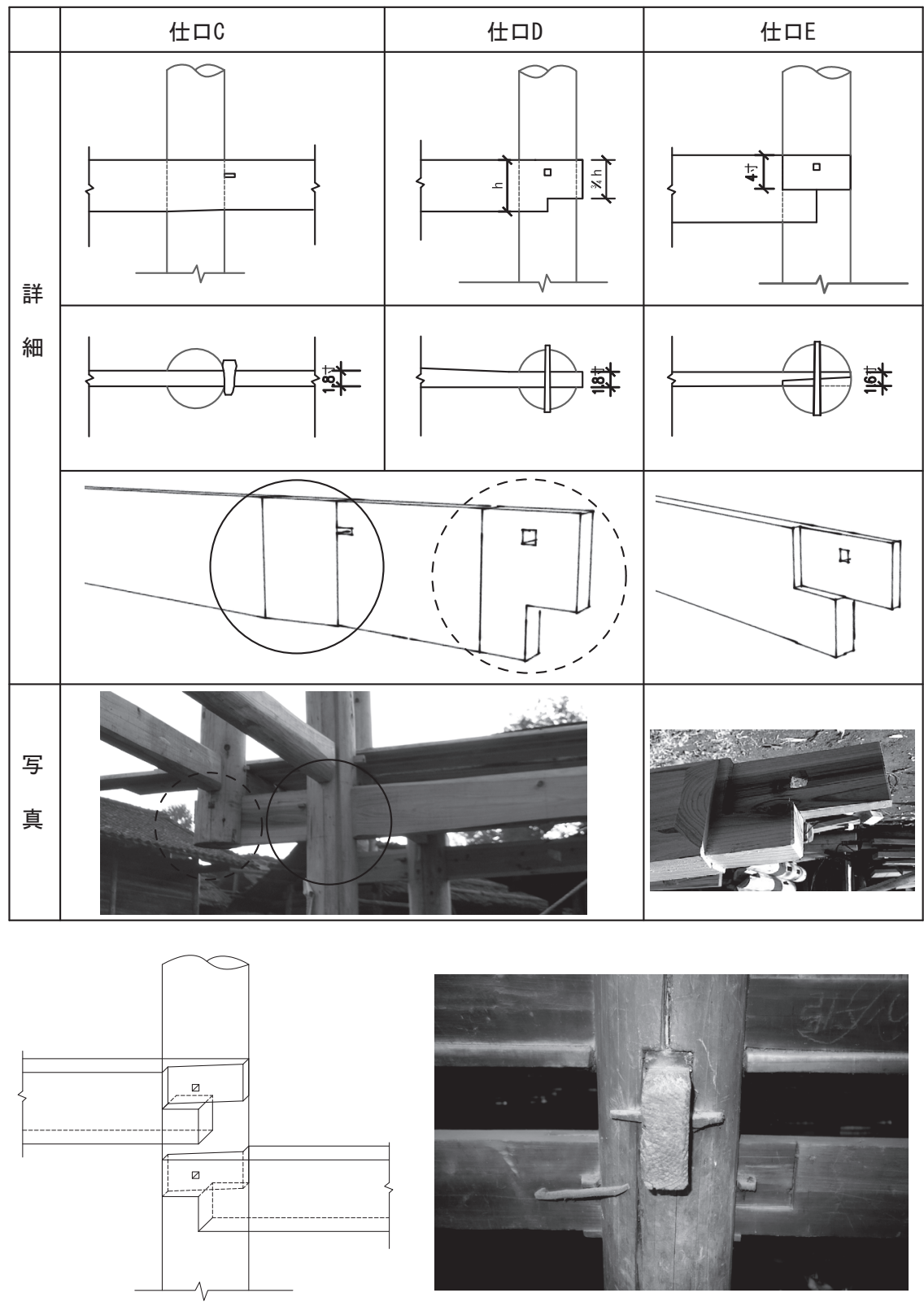

図 9 仕口 $\mathrm{E}$ の接合概念図

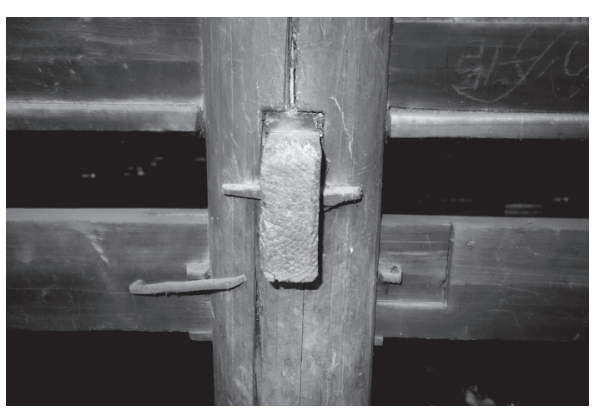

写真 3 柱の両側に栓を打った仕口

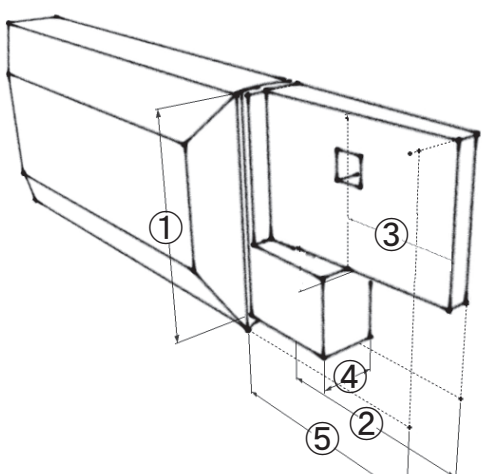

図 10 短竹尺の記号情報の解明

(5)

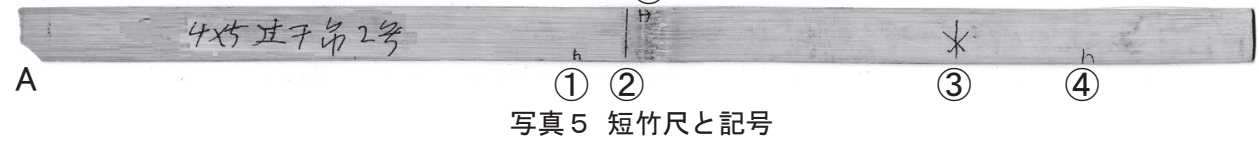


竹尺」と呼ばれる薄く削った竹片を接合部毎に 1 枚ずつ作成する（ 写真 4)。短竹尺の記号と柄との対応を写真 4 に示寸。

最も複雑な仕口 $\mathrm{E}$ を取り上げて短竹尺の記号と仕口の対応を示す。 図 10 は写真 3 に対応して作られた仕口である。短竹尺の「 $4 \times 5$ 過干吊 2 号」は「4 排 5 柱側の吊柱の 2 号過干枋 $2 」$ の柿の寸法で あることを示している。(1)は柄の高さ、(2)は長さ、(3)は中心線の位置、 (4)は柄の幅である。柄穴の長さが手前と後ろでずれる場合があるが、 このずれを(5)で示す。一つの柄穴に一本の短竹尺を用い、仕口 E は、 両方からの枋材を一つの柄穴で接合するため、短竹尺に枋の挿寸方 向を記し（写真 3 A の切り欠き部分）二回使用する。

\section{5. 枋材と仕口}

本章では、仕口 C、D、E が用いられ軸組で最も重要な部材の「千 金枋（上）」、仕口 C、D が用いられ小屋組と軒を支える「水枋（下）」、 仕口 A、B に用いられる小屋組の「中柱瓜枋 $2 」$ 」取り上げ、枋材の 詳細と五つの仕口の組み合わせを述べる。

\section{1 千金枋（上）}

一本の枋は両端以外で 1 本以上の柱を水平方向に貫通する際「進 大出小」の寸法の特徴がある注 31 。枋材が柄穴に入る方が「進」、出 るほうが「出」であり、「進」が「出」より 0.1 寸 (3. 3mm) から 0.2 寸 (6. 6mm) 大きい。枋の「出」は「進」より小さく、貫通する柱は「出」 の方向に動きやすいため、枋材と柱が仕口 C で接合する場合、栓は 柱の「出」に沿って打たれ、柱は枋から抜ける動きを抑える。

千金枋（上）は仕口C で 4 柱を貫通し 3 柱に仕口 E を用い、反対 側から差し込まれた千金枋（下）の柄と接合する（図 11）5柱、吊 柱が動いて 5 柱と仕口 C で接合し、吊柱と仕口 D で接合する。組み 立ての手順（図 12）によって、図 11 のア点、イ点、ウ点、工点はそ れぞれ「出」、「進」、「進」「出」となり、高さは 8 寸 $(264 \mathrm{~mm}) 、 8.2$ 寸 $(271 \mathrm{~mm}) 、 8.3(8.1)$ 寸 $(274 \mathrm{~mm}(267 \mathrm{~mm})) 、 7.9$ 寸 $(261 \mathrm{~mm})$ となって いる。柄の幅は仕口 E が 1.6 寸 (52.8mm)、その他は 1.8 寸 (59.4mm) である。 5 柱、 4 柱の動きを抑えるため、仕口Cに用いられる栓は 柄穴の「出」の方、寸なわちア点、工点に沿って打たれる。枋の端
にある柱は仕口 D、Eで込栓が用いられた。

枋は幅 2.2 寸 (73mm) 以上の板材を用いて加工されたが、柄穴の幅 は 1.6 寸 $(52.8 \mathrm{~mm})$ か 1.8 寸 $(59.4 \mathrm{~mm})$ である。排扇枋が柱を貫通し ない部分と瓜枋が瓜柱に架からない部分は枋材の幅を削らない。こ のため、千金枋（上）（図 11）の膨らんでいる部分は、柱が貫通し ないために加工されず、元の板材の寸法になっている。

\section{2 水枋 (下)}

水枋は小屋組の荷重を受ける部材であり、吊柱より外側の部分は 軒となる。水枋（下）は左側から 1 柱、2 柱吊柱の順に貫通させ、 反対側の柄を 2 柱に差し込む（図 13）。水枋下は 1 柱と吊柱を仕口 C で貫通し、2 柱と仕口 D で接続する（図 14）。2 柱と 1 柱の間は仕 口A で瓜柱 2 (下)、瓜柱 1 (下) が架かる。1 柱の柄穴を「進」と すると、吊柱の柄穴が「出」になると同時に、それぞれの柱の柄穴 の左が「進」で、右が「出」となる。「進大出小」に従って水枋の高 さは図 13 で示すとおり、ア点（進）6 寸 (198mm)、イ点（出) 5.8 寸 $(191 \mathrm{~mm}) 、$ ウ点（進) 5.8 寸 $(191 \mathrm{~mm}) 、$ 工点（出） 5.6 寸 $(185 \mathrm{~mm}$ )、 才点 5.5 寸 $(182 \mathrm{~mm})$ となっている。柄の幅は 1.8 寸 $(59.4 \mathrm{~mm}) 1.6$ 寸 (52. $8 \mathrm{~mm})$ であった。 1 柱と 1 柱吊柱が動かないように、柱の柄穴の 「出」に沿って栓を打つ。水枋（下）は 1 柱吊柱の外側に小屋組の桁 がかかるため、端に用いられる仕口 D ではなく、仕口 C が用いられる。 千金枋（上）と同様に枋材の膨らみは板材の加工前の寸法である。

\section{5 . 3 中柱瓜枋 2}

中柱瓜枋 2 は中柱を貫通し、両端は仕口 B で「瓜柱 5 上」と「瓜 柱 5 下」と接合し、中柱と瓜柱 5 の間に仕口 A で「瓜柱 6 上」と「瓜 柱 6 下」が架かる (図 15)。組みたての手順は、枋材は左から中柱 を貫通させ「瓜柱 5 下」と接合し、反対側の柄は「瓜柱 5 上」に差 し込んだのち、瓜柱 6 の上下 2 本を架ける（図 16）。「進大出小」に 従って、中柱の柄穴は左のア点が「進」であり、右のイ点が「出」で、 イ点の高さは左のア点より 0.1 寸 $(3.3 \mathrm{~mm})$ 短く、仕口の幅は 1.6 寸 (52. $8 \mathrm{~mm})$ と一定である。柱が通らず、瓜柱が架からない部分は膨ら んでいる。
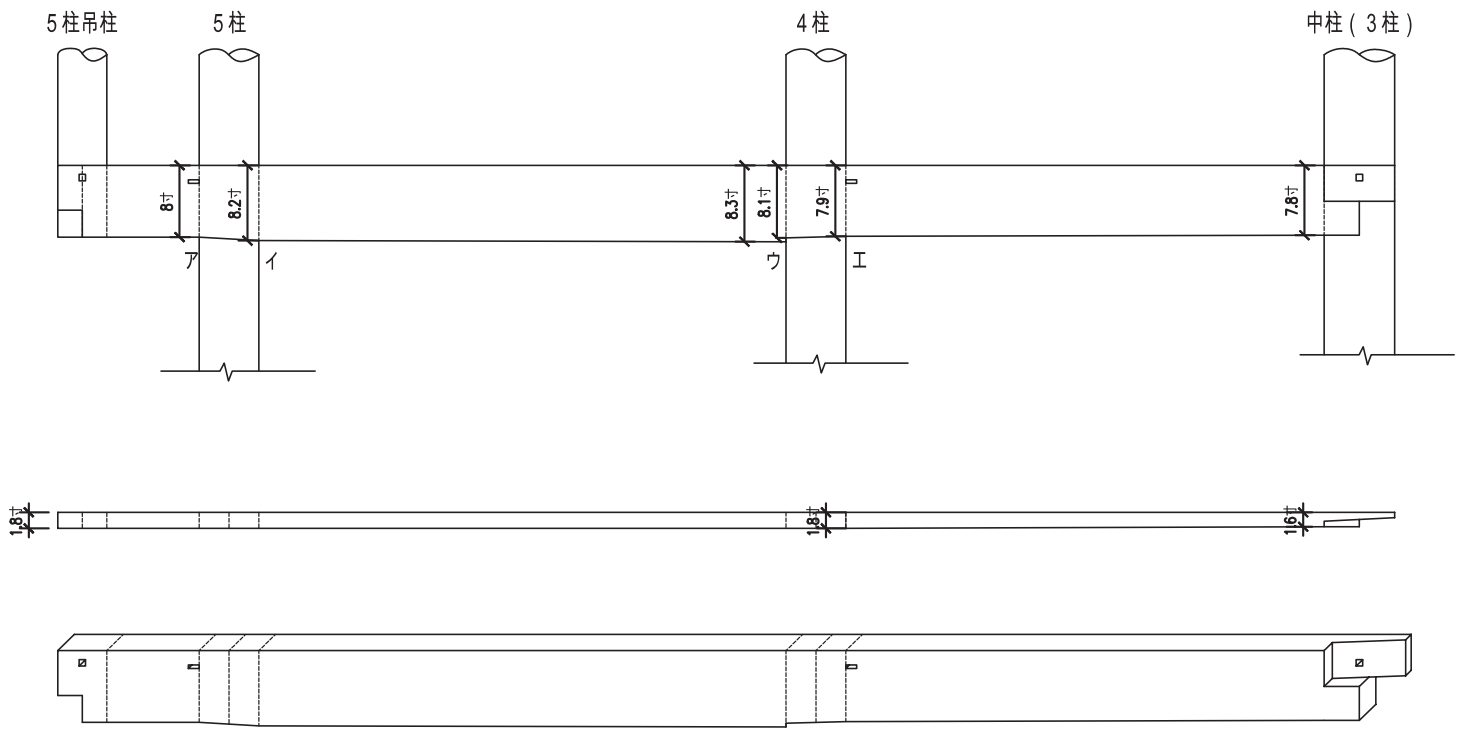

図 11 千金枋（上）の寸法詳細 


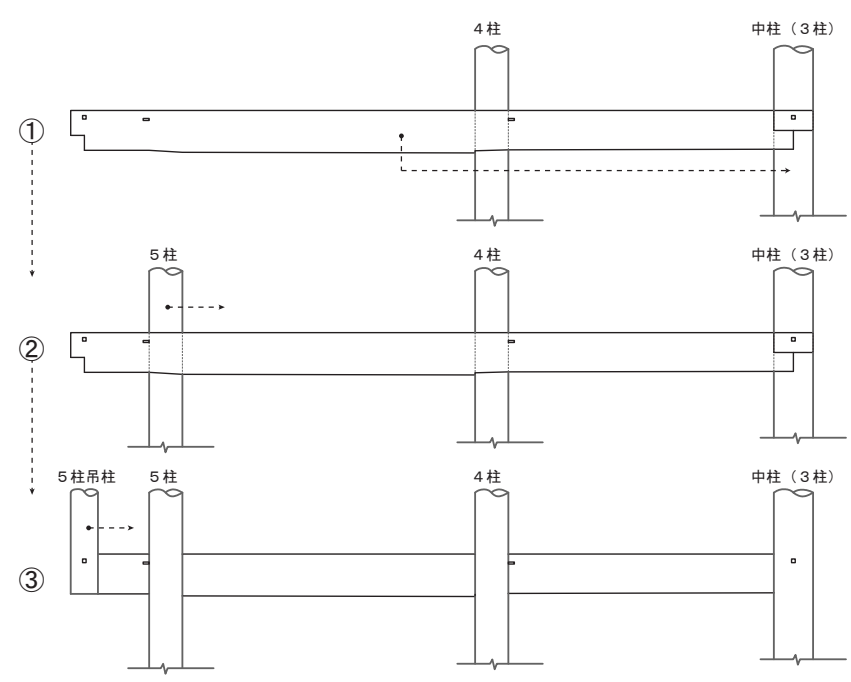

図 12 千金枋（上）の組み建て手順

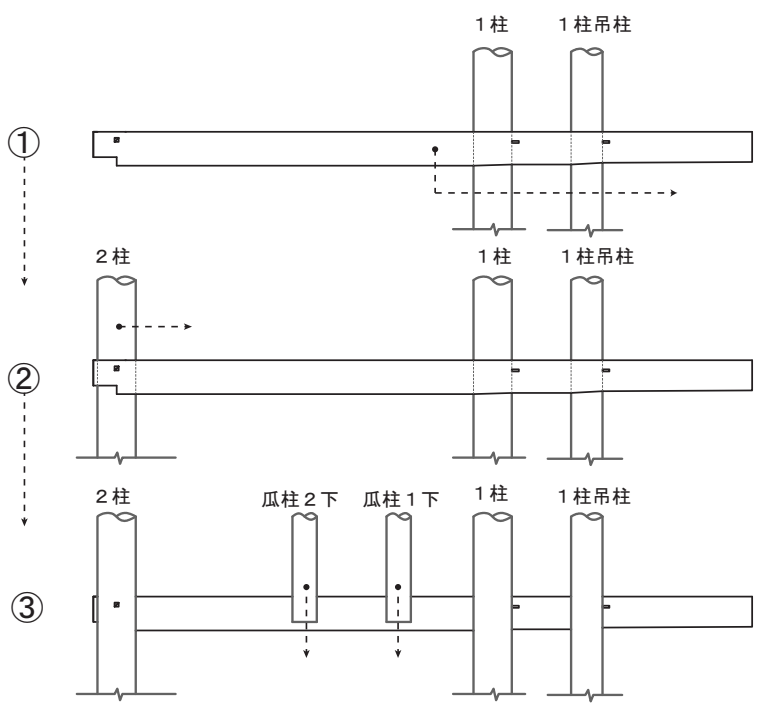

図 13 水枋（下）の組み建て手順

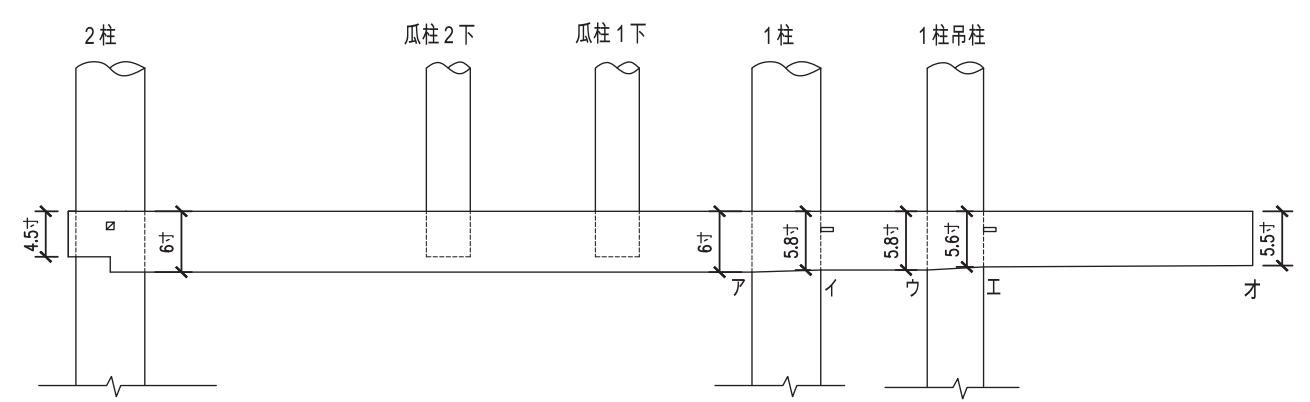

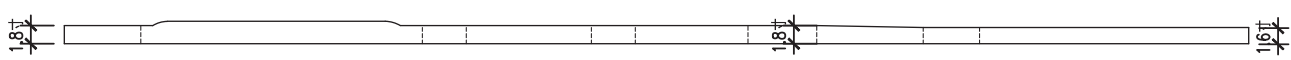

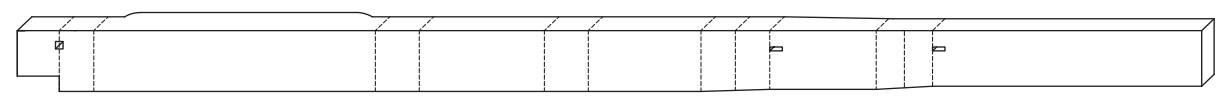

図 14 水枋（下）の寸法詳細

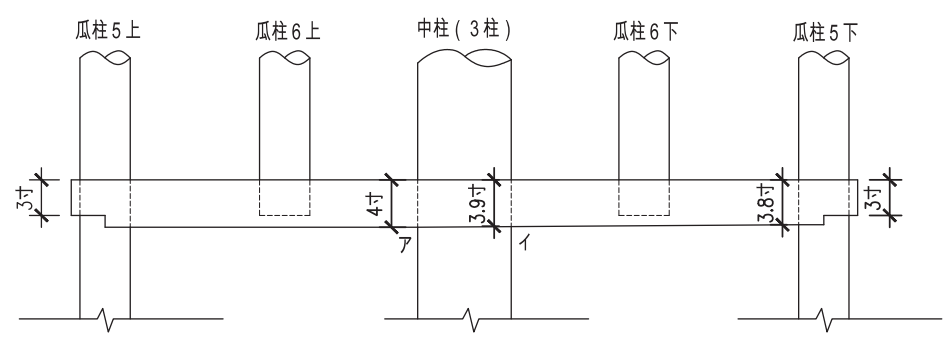

策

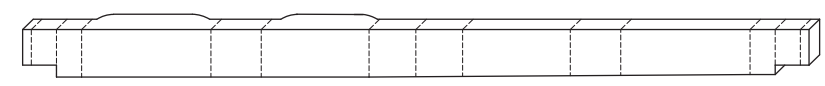

図 15 中柱瓜枋 2 の寸法詳細

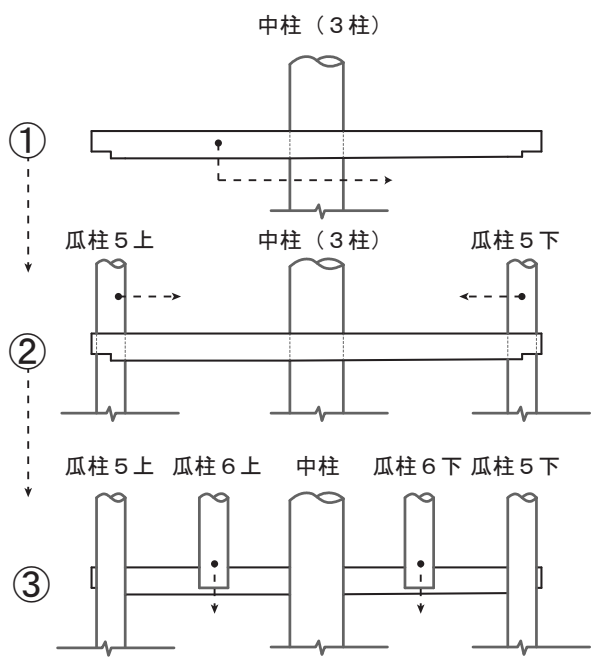

図 16 中柱瓜枋 2 の組み建て手順 


\section{6. まとめ}

本研究は貴州省黔東南地域における穿闘式木造民家を対象に以下 の 5 点を明らかにした。(1)穿闘式木造民家の架構は柱と枋で構成さ れ、最も重要な接合構法は 2 本に枋が柱の両側から挿し柱の柄穴で 接合するのである。(2)現在は部材の名称は、簡単な漢字と数字を組 み合わせて表す。(3)「枋」について、既往研究で指摘された「進大 出小」は「進」と「出」を交互に組み合わせることで柱の動きを相 殺する工夫がある。(4)仕口は 5 種類あり、小屋組の瓜柱と瓜枋の接 合には込栓を使用しないが、柱と排扇枋の接合は左右の動きを止め る「栓」あるいは上下左右の動きを同時に止める「込栓」が使用される。 (5)「枋」は差し込むところのみを削り、それ以外の厚みを残すことで、 差し込みと逆方向の動きを止めることができる。

明らかになった柱と枋の動きから、仕口の組み合わせと枋材本体 の加工が工夫され、組み立てを効率良く進めるために接合点が少な く簡素な構法が生み出されたと考えられる。このため、大工による 加工は比較的複雑な木工技術が必要とされる一方、組み立ては一般 の村民による「挿す」と「吒く」という簡単な動作だけで堅牢な架 構を完成させることが可能である。多くの「力」を短時間に効率良 く利用できる構法が生多出されたと考えられる。

本研究は科学研究費補助金（基盤研究 (A))「東アジアにおける植 物資源の高度循環利用に基づく居住環境の地域特性に関する研究」（ 代表：安藤邦廣、課題番号：23246104）により行われたものである。

\section{参考文献}

1）片岡靖夫, 北守顕久, 越智弘幸, 小松幸平 : 中国トン族の杉による伝統木 造建造物の研究 第 1 報貫構造による鼓楼の構造と構築システム, 日本建 築学会構造系論文集 第 622 号,pp137-144,2007. 12

2 ) 田中淡, 浅川滋男ほか（貴州トン族住居調査委員会）：中国・貴州の高床 住居と集落一黔東南トン族とその周辺，住宅建築, 1990.4

3 ) 田中淡, 浅川滋男ほか（貴州トン族住居調査委員会）: 蘇洞・トン族の村 と生活，住宅建築 1993 年 4,pp. 4-107, 1993

4) 李先迬 : 干闌式苗居建築, 中国建築工業出版社, 2005

5 ) 羅徳啓：貴州民居，中国建築工業出版社,p157, 2008

6 ) 張欣 : 苗族吊脚楼伝統営造技芸, 安徽科学技術出版社, 2013

7 ) 李雪、黒田乃生、藤川昌樹、安藤邦廣 : 中国貴州省における少数民族の 穿闘式木造民家の建設工程と生産組織に関する研究一黔東南ミャオ族卜 ン族自治州公納村を対象として一, 日本建築学会計画系論文集 第 721 号 ,pp603-612, 2016. 3

8 ）片岡靖夫、北守顕久、越智弘幸、小松幸平、脇田健裕：中国トン族の杉に よる伝統木造建造物の研究 第 2 報 貫構造による各種建造物の構築システ ムと木割り，日本建築学会構造系論文集＼cjkstart第 664 号, pp1101-1108, 2011.6

注

注 1 )『穿闘式架構は「立帖式架構」ともいい、中国の西南地方で多く用いら れている。母屋の桁ごとに一本ずつ通し柱を立て、横梁を用いないの が特徵である。』とされている。（田中淡訳編: 中国建築史編集委員会編: 中国建築の歴史, 平凡社, p346, 1981)

注 2 )『懸造り（かけづくり）式の住居で、傾斜地を整形した土間領域から板 張りの床をせりださせた『半高床』式の床構造をもつ。』とされてい る。(田中淡訳編 : 中国建築史編集委員会編 : 中国建築の歴史, 平凡社 , p37, 1981)

注 3 ) 黔東南地域の集落に在住する大工は民家の建設で得る収入だけでは生活 できないため、農業を生業とする兼業大工であり、近年は都会に出稼 ぎに行くこともある。」とれている。(参考文献 7 ) )

注 4 ）農村と都市の格差を是正する目的で中国政府は 2005 年に「新農村建設」 の方針を打ち出した。これによって上下水道や道路舗装などのインフ ラ整備、集住を目的としたあらたな居住地の建設が進められた。（烏日 図、星野敏：中国における新農村建設と都市・農村一体化政策, 農村
計画学会誌 25, pp. 515-520, 2006. 12. 30)

注 5 ) 図 2 で示しているように、「梢構法」、「歯構法」、「ホゾ構法」、「歯梢構法」 である。

注 6 ) 参考文献 1 )

注 7 ）仕口を精度良く架構するため、大工が仕口加工ための記号情報と寸法情 報を記載した短竹尺と長竹尺を自ら製作する（参考文献 8 ))。本論文 は 4.2 で短竹尺について討論した。

注 8 ） 2013 年 6 月から 2013 年 11 月までに黔東南ミヤオ族トン族自治州にあ る 14 ケ村（増沖、小黄、占里、ビャーパー、付中、巨洞、架里、ビヤ ーシャー、銀潭、大洞、則里、流架、会里、公納）の予備調査を行った。

注 9 ）参考文献 2)

注 10）公納村はミャオ族が生活しており、現在約 110 世帯、590人が居住する 従江県は平均的な規模の村であり、村の経済基盤は農業である。

注 11） 2014 年に実施した悉皆調査によると、公納村における 109 棟の木造民 家には構造および間取りの変遷が見られる。G家に用いられる構法は 2010 年から主流になった構法である。本論文は現在の建設活動と構法 を明らかにすることを目的としているため、民家の変遷は別稿で報告 する。

注 12）黔東南地域の木造民家の建設は、上棟を終えると、残りの外壁の板張 りや内装などの工事を施主の都合によってゆっくり完成させる場合が 多い。G 家の場合、2004 年 7 月の調査の時に外壁はまだ未完成の状態 なので、立面図と断面図は 2013 年の調査当時に上棟された架構を基づ いて作成し、平面図は 2014 年 7 月の使用状態を表している。

注 13）「枋」は黔東南地域の穿闘式木造民家の横架材の総称であり、柱を貫通 する機能を持っている。 5 章で述べたように、一本の枋に位置によっ て高さや幅に変化があるため、日本の「貫」と少し異なる特質がある。

注 14）公納村では、梁行の小屋組付きの架構は「扇」と呼ばれ、「扇」を組み 立てる建設工程は「排扇 (パイシャン)」という。ここの「排」は組み 立てるという意味で、柱を貫通する枋は「排扇枋」と呼ばれる。

注 15）黔東南地域の方言で「干」と「間」との発音は同一で、過干枋」の「干」 は間口を表す「間」に相当することが考えられる。「過」は「渡す」と いう意味であることから、過干枋」は「過間枋」で理解すると、間口「間」 を渡す枋材と理解できる。

注 16）前掲 14）

注 17）柱の位置の順番から「3」柱がちょうど中央になり、G家の架構では最 も長く重要な柱だった。また「中柱」は中央の柱なので、G家の架構で は「中柱」と「3柱」が同じになった。

注 18） G 家の穿闘式架構の 1 柱と 5 柱は基礎から桁まで伸びているが、公納村 の他の民家では、1 柱と 5 柱が 2 階の床までの事例も見られた。

注 19）参考文献 3)

注 20)「千斤」でもある。極大な重量を持つ枋とも考えられる。

注 21）参考文献 5）,p142

注 22)「枋」と同一と考えられる。

注 23）参考文献 7)

注 24）大工の聞き取りによると、工事の都合（天気や人工数など）によって、 「排扇」は「扇」の軸組だけを組み立て、翌日の「上棟」に小屋組部分 を架ける場合もあるという。

注 25）参考文献 7)

注 26）大工への聞き取りによると、用意できる木材の寸法の制限により、出 水枋と千金枋は上下の 2 本組でなく、上中下の 3 本組が用いられる場 合もあるが、2本組が最優選択肢だという。

注 27）参考文献 8)

注 28) 参考文献 8)

注 29）仕口E は李（2005）（参考文献 5）p76）が示した「単梢構法」（図 2） と同じである可能性が高いが、図面と説明からは明確ではない。

注 30）参考文献 7)

注 31）参考文献 5）,p142 


\title{
THE STRUCTURE AND TIMBER CONNECTION OF \\ CHUANDOU-SYSTEM WOODEN HOUSES OF MIAO NATIONALITY
}

- A study on the construction method of chuandou-system wooden houses of minority nationality in Guizhou Province, China -

\author{
Xue LI* ${ }^{*}$, Nobu KURODA**, Masaki FUJIKAWA *** \\ and Kunihiro ANDO **** \\ * Doctal program, World Heritage studies, Graduate School of Comprehensive Human Science, University of Tsukuba, M.Eng. \\ ** Prof., Faculty of Art and Design, University of Tsukuba, Ph.D. \\ *** Prof., Faculty of Engineering, Information and Systems, University of Tsukuba, Dr.Eng. \\ **** Honorary Prof., University of Tsukuba, Dr.Eng.
}

The Chuandou System (pillars-and-transverse-tie-beams) wooden frame is wildly used in M iao people's houses in Qiandongnan region of Guizhou Province of China. The Chuandou System wooden frame is composed of vertical pillars and horizontal beams called "Fang". In this area, the house building is following a traditional production organization that the local carpenters design the house and process wooden components and the setting-up of the frame that is completed by joint work of villagers. By investigating the construction process of $G$ house in Gongna V illage, Qiandongnan region, this study has clarified that five types of the mortise and tenon joints are used in Chuandou-systerm wooden. The dimension characters of horizontal beams (Fang) were also clarified. In addition, the relationship between types of mortise and tenon joints, the dimension characters of horizontal beams (Fang), and the production organization of house building would be discussed in this study.

In G house, the wooden frame could be separated into roof truss and framework. There are two types of mortise and tenon joints in roof trusses. . One of the joints that carpenters cult into a cavity in bottom of short pillar, and the cavity could be used as a mortise to put the short pillar on horizontal beam. A nother type of the joints could be considered as a "haunched stob tenon joint", which is used to put horizontal beams(Fang) into short pillars. A Iso, there are three types of mortise and tenon joints in the frameworks. One type could be considered as a "pegged tenon joint". A haunched stob form tenon on the end of the beam inserts into the mortise. For strengthening the mortise and tenon, a peg is drived into one hole both through mortise and tenon. In another type of joints, tenon is in the middle of the horizontal beam (Fang) that could be passed across mortise and a key could be drived into horizontal beam (Fang) close to the pillar. The last type of mortise and tenon joints also could be considered as a "pegged tenon joint". Pair of horizontal symmetry beams come from two sides of the pillar, and two tenons on the end of beams are joint in one mortise. A peg also has been drvied into two tenons and one mortise to fix them.

A fter the processing of wooden components, local villagers have to set up the Chuandou system frame by a very simple way in two days. They move horizontal beams (Fang) or vertical pillars to join mortises and tenons, and use wooden hammers to hit the beams to strengthen the connection of mortise and tenons. To provide an effectively setting-up construction, the local carpenters should devise the combination of mortise and tenon joints, and also process the horizontal beams (Fang) by different heights and widths in different positions even in the same beam as the shorter area can ensure the beams insert mortise smoothly. Therefore, relatively complicated process skill as well as a simple setting-up frame is developed in this region. 